temperate rainforest covered the region. A combination of low inter-annual climate variability (ENSO-related), declining strength of the Asian monsoon, and low intensity of Aboriginal occupation in the rainforests likely caused low charcoal quantities and fire-event frequencies. It was not until around 4 cal ka BP that charcoal quantities and fire-event frequencies rose across the region, peaking in the last 2 ka. Holocene El Niño activity has been highest in the last $2 \mathrm{ka}$ and may have been a significant cause of drought and greater potential fire ignition over this time. This period also coincides with evidence for increased Aboriginal site occupation and the adoption of more complex foodextraction strategies and intensive use of rainforest resources (Turney and Hobbs, 2006; Cosgrove et al., 2007).

\section{Concluding remarks}

The comparison of charcoal records with climate and human impact proxies in the Wet Tropics of Australia reveals the complexity inherent in fire dynamics through time. There are corresponding peaks in fire-event frequencies and millennialscale climate changes in the North Atlan- tic (Bond et al., 2001; Turney et al., 2005) and regional climate drivers (El Niño activity) that may have influenced fire ignition in the wet tropic rainforests of Australia through the Holocene. However, no single driver can explain past fire patterns and many events may be the result of multiple drivers (climate-vegetation-people) interacting on differing temporal and spatial scales. It also remains unclear whether or not Northern Hemisphere millennialscale climate changes had an impact on the Australian tropics (Turney et al., 2004). In Australia, current severe drought and plant mortality are increasing fire hazard and raising concerns about the trajectory of post-fire vegetation change and future fire regimes (Lynch et al., 2007; Bowman et al., 2009). Understanding the interaction between multiple drivers of fire and fire-events from the past will be critical information for managing fire regimes in Australia in the future.

\section{Data}

The Lake Euramoo and Quincan Crater data are available upon request from the first author. Data shown in Figure 1 are from the Indo-Pacific Pollen Database http://palaeoworks.anu.edu. au/databases.html and the Global Palaeofire
Database http://www.bridge.bris.ac.uk/projects/ QUEST_IGBP_Global_Palaeofire_WG/index.html).

\section{Acknowledgements}

This work is financially supported by the Australian Research Council (Grants DP0986579, DP0664898 and DP0210363) and Australian Institute for Nuclear Science and Engineering (Grant ANGRA00060), and the Australian Nuclear Science and Technology Organisation.

\section{References}

Cosgrove, R., Field, J. and Ferrier, A., 2007: The archaeology of Australia's tropical rainforests, Palaeogeography, Palaeodlimatology, Palaeoecology, 251: 150-173.

Haberle, S.G., 2005: A 23,000-yr pollen record from Lake Euramoo, Wet Tropics of NE Queensland, Australia, Quaternary Research, 64 343-356

Higuera, P.E., Brubaker, L.B., Anderson, P.M., Hu, F.S. and Brown, T.A., 2009: Vegetation mediated the impacts of postglacial climatic change on fire regimes in the south-central Brooks Range, Alaska, Ecological Monographs, 79: 201-219.

Kershaw, A.P., Bretherton, S.C. and van der Kaars, S., 2007: A complete pollen record of the last 230 ka from Lynch's Crater, north-eastern Australia, Palaeogeography, Palaeoclimatology, Palaeoecology, 251: 23-45.

Lynch, A.H., Beringer, J., Kershaw, A.P., Marshall, A., Mooney, S., Tapper, N., Turney, C. and Van Der Kaars, S., 2007: Using the paleorecord to evaluate climate and fire interactions in Australia, Annual Review of Earth and Planetary Sciences, 35: 215-39.

For full references please consult:

http://www.pages-igbp.org/products/newsletters/ref2010_2.html

\title{
Humans and fire: Consequences of anthropogenic burning during the past 2 ka
}

\author{
Jennifer R. Marlon ${ }^{1}$, Q. Cui ${ }^{2}$, M.-J. Gaillard ${ }^{2}$, D. McWethy ${ }^{3}$ and M. Walsh ${ }^{1}$ \\ 'University of Oregon, Eugene, USA; jmarlon@uoregon.edu \\ LLinnaeus University, Kalmar, Sweden; ${ }^{3}$ Montana State University, Bozeman, USA
}

\section{Holocene sedimentary charcoal records document human influences on biomass burning around the world, with global-scale consequences in the past two centuries.}

A global network of sedimentary charcoal records (Fig. 1a; Power et al., 2008) has shown that trends in biomass burning that were long controlled by climate (including $\mathrm{CO}_{2}$ changes) have now come to be driven primarily by people (Fig. 2a-d; Marlon et al., 2008). Three case studies from western North America, New Zealand and Europe demonstrate the spatiotemporal variability of human impacts on fire regimes and vegetation and illustrate why local impacts do not aggregate to distinct broadscale signals until the very recent past.

\section{Western North America}

In the Pacific Northwest, paleoecological records illustrate a wide range of climatic and human influences on fire regimes during the past $2 \mathrm{ka}$. For example, at Battle Ground Lake (conifer forest; Washington State), fire occurrence tracked climatic changes prior to Euro-American settle- ment (ca. AD 1830), most notably showing high fire activity during the Medieval Climate Anomaly (MCA; ca. AD 950-1250) and almost no fires during the Little Ice Age (LIA; ca. AD 1450-1850) (Fig. 1b; Walsh et al., 2008)-a pattern characteristic of many other sites in western North America (Marlon et al., 2006). These shifts seemingly occurred in the absence of major vegetation changes, suggesting little association with Native American landuse (fire was used to create more open and resource-rich landscapes). Following Euro-American settlement, fire occurrence was more clearly influenced by human activity, with a large-magnitude fire event in AD 1902 and little to no fire in the last 100 years. In contrast, fire activity at Lake Oswego (oak woodland; Oregon) was likely the result of anthropogenic burning modulated by regional climate variability. Fire activity generally increased ca. AD 0-1000 despite cooling summer temperatures, suggesting land-use intensification by Native Americans (Fig. 1c) (Walsh et al., in press). By approximately AD 1000, higher fire activity, possibly aided by warmer drier conditions during the MCA, forced a sharp decline in forest cover near the site and an increase in grasses and other disturbancetolerant taxa. Frequent burning continued until the onset of the LIA (ca. AD 1450), at which time fires decreased and forest cover subsequently increased. The timing of this regime shift could be associated with the collapse of Native American populations following Euro-American contact (Boyd, 1999) or reduced ignitions and fireconducive weather during the LIA. Little to no fire activity has occurred at Lake Oswego in the last 300 years. Thus, the extent of human impacts on fire regimes in the Pacific Northwest appears closely linked to the spatial configuration of vegetation 


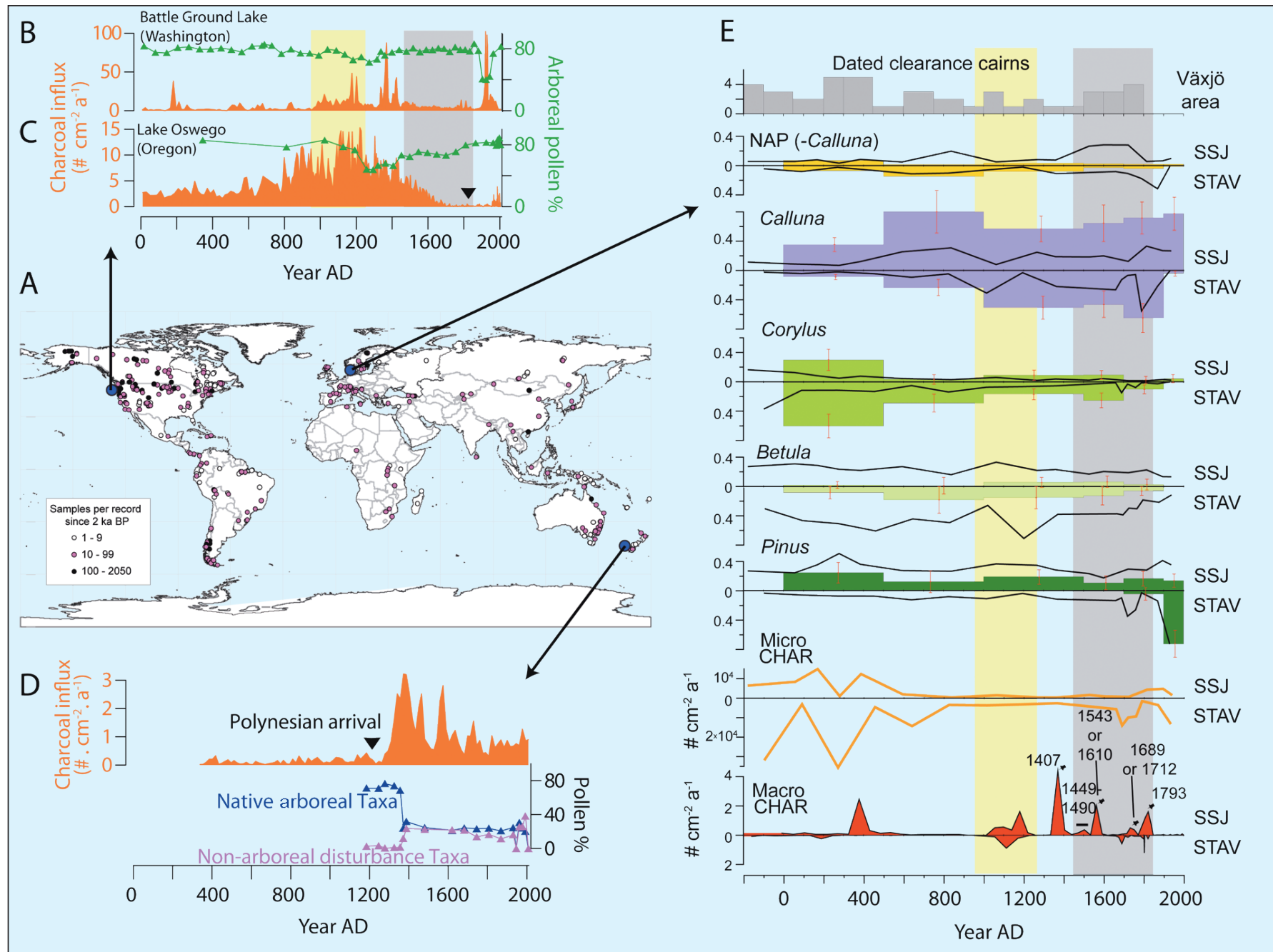

Figure 1: A) Sites of paleofire reconstructions in the Global Charcoal Database (Marlon et al., 2008; Power et al., 2008); Macrocharcoal influx (CHAR; orange) and changes in \% arboreal pollen (green) from (B) Battle Ground Lake and (C) Lake Oswego. Black triangle indicates timing of Euro-American arrival ( AD 1830), yellow shading on all plots indicates timing of Medieval Climate Anomaly, gray shading indicates timing of the Little Ice Age; D) Diamond Lake (New Zealand) CHAR (orange) and changes in pollen \% of arboreal taxa (blue), primarily beech and podocarps, and non arboreal pollen (NAP) taxa (violet), primarily grasses and bracken fern associated with Polynesian arrival and increased CHAR during the initial burning period ca. 1300-1600 AD; E) records of CHAR (red) and microscopic charcoal (orange; counted in pollen slides) from Stavsåkra (STAV) and Storasjö (SSJ), and model-derived estimates of local abundance (in proportion to cover of vegetation) of main tree taxa ( $3 \times$ green) and NAP (purple and yellow) within the relevant source area of pollen (RSAP; Sugita, 1994), 750-1500 m radius in the case of these two sites during the last $2 \mathrm{ka}$. The model used was the LOVE (LOcal Vegetation Estimates) model (Sugita, 2007a; 2007b), which estimates plant cover within the RSAP of small basins (lakes or bogs) from pollen records. Estimates were calculated for 500-a intervals except in the recent time, AD 1500-1700, AD 1700-1900, and AD 1900-2000 and are overlain by pollen \% (thin black lines). A tentative correlation between the CHAR peaks and fire events dated by dendrochronological analysis of fire scars at Storasjö (Wäglind, 2004) is proposed. The top gray plot shows frequency of dated clearing cairns per 100-a interval in the Växjö region (Skoglund, 2005), documenting extensive forest clearing by burning.

communities and human land-use intensity within those ecosystems.

\section{New Zealand}

In contrast to Australia where natural fires are common and the influence of humans on patterns of fire is complex (Lynch et al., 2007), New Zealand presents a unique example where deliberate and repeated burning by a relatively small human population overwhelmed strong climatic constraints limiting fire (occurring only once every 1-2 millennia; Ogden et al., 1998) and enacted large-scale deforestation of closed-canopy forests. Paleoecological data from New Zealand indicate widespread deforestation of native forests soon after the first known presence of Polynesians (Māori), ca. AD 1280 (McGlone and Wilmshurst, 1999; Wilmshurst et al., 2008). Charcoal and pollen data from lakesediment cores throughout central South
Island show a prominent period of initial burning that consists of one to three fire episodes (i.e., several fire events occurring within a few years) within 100 years (Fig. 1d; McWethy et al., 2009). This initial burning period is associated with a major decline in forest taxa, increased erosion, and elevated levels of grass and bracken (ferns). By the time Europeans arrived in the $18^{\text {th }}$ century, over $40 \%$ of the South Island was deforested and native closedcanopy forests were replaced by open vegetation (Fig. 1e; McGlone, 1983; Fig. 2e, Mark and McLennan, 2005). Contrary to examples of deforestation linked to intensive human population pressure (Heckenberger et al., 2007), populations on South Island were estimated to be small, with founding numbers at approximately 100-200 individuals (Murray-Mclntosh et al., 1998). Paleoclimatic data from treering and speleothem archives suggest that abrupt deforestation occurred in the absence of climate change (Lorrey et al., 2008). Hence, the transformation of large landscapes was apparently achieved by the concerted burning efforts of small transient populations acting largely as hunter-gatherers.

\section{Europe and southern Sweden}

Many paleoecological studies have demonstrated anthropogenic influences on fire regimes of central and southern Europe since Neolithic time (e.g., Tinner et al., 2005, 2009; Vannière et al., 2008; Carcaillet et al., 2009). Climate impacts on fire regimes were prominent during the early and mid Holocene but became increasingly masked by the human use of fire during the late Holocene (e.g., Vannière et al., 2008; Kaltenrieder et al., 2010). Conversely, in parts of southern Europe (e.g., Northern Italy), widespread arboriculture (e.g., 


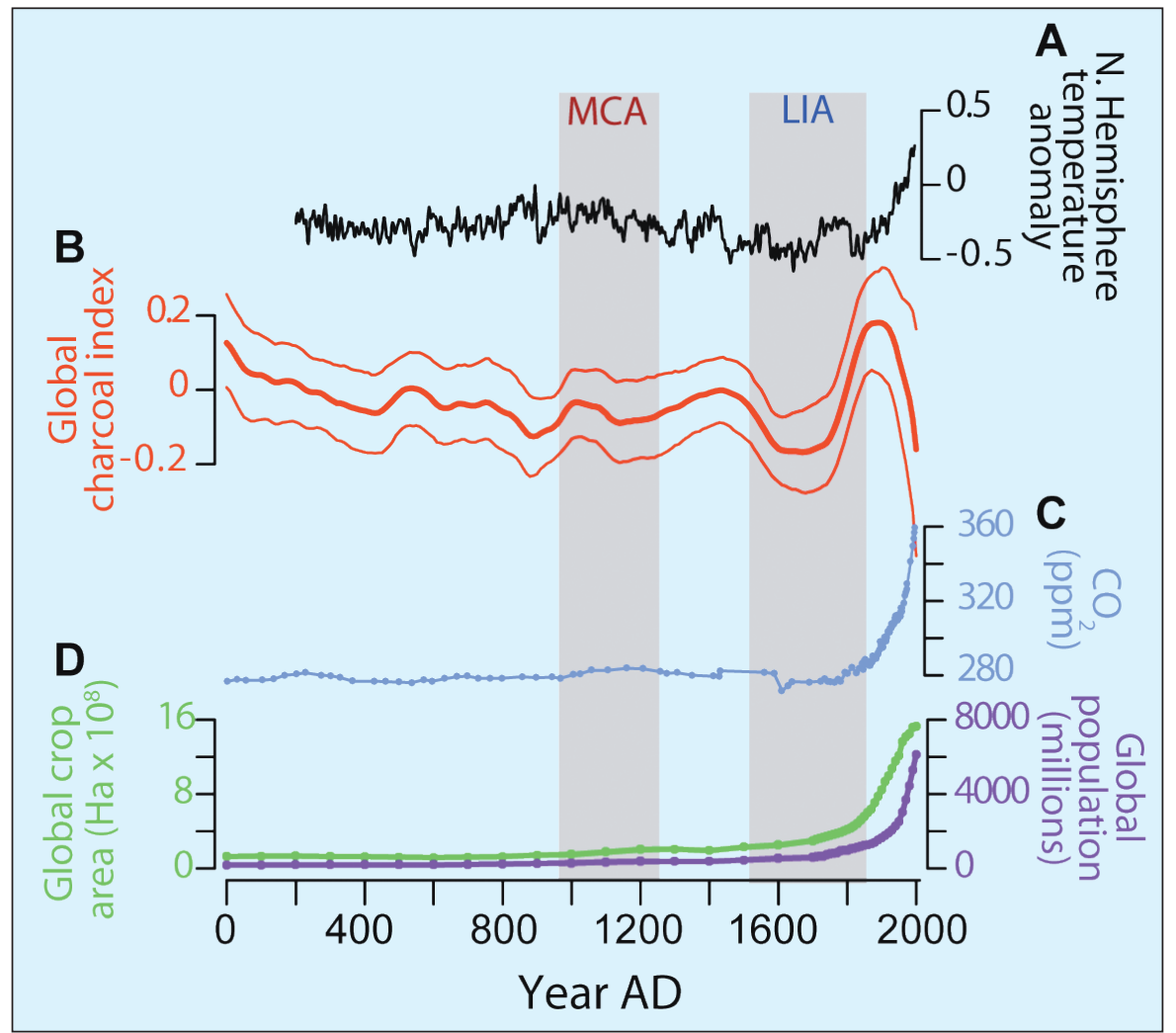

Figure 2: Reconstructions of (A) Northern Hemisphere temperature anomalies (black; Jones and Mann, 2004), (B) global biomass burning with confidence intervals based on bootstrap resampling by site (red; Marlon et al., 2008), (C) atmospheric $\mathrm{CO}_{2}$ concentration (blue; Meure et al., 2006), which was likely responsible for the peak in fire prior to 1850, and (D) global population (purple) and agricultural land cover (green) from the HYDE 3.1 database (Klein Goldewijket al., 2010). The Medieval Climate Anomaly (MCA) and Little Ice Age (LIA) are represented by the gray bars. This figure shows that global biomass burning and Northern Hemisphere temperatures both generally declined during the past 2 ka despite increasing human populations; human influences on global biomass burning are readily apparent during the past two centuries when agriculture, grazing and other human influences expanded rapidly.

the cultivation/management of Castanea sativa) required fire suppression during the past 2 ka (Conedera et al., 2004). The strong decline of land use in marginal areas of southern Europe has caused an expansion of shrublands and forests and increasing fires after the 1950s (Moreno et al., 1998) mirrored in sedimentary charcoal content (e.g., Tinner et al., 1998). In northwestern Europe, climate may have acted as a primary control on fire activity during the early and mid Holocene (Carcaillet et al., 2007; Greisman and Gaillard, 2009), whereas human impacts were as (or more) important during the late Holocene (e.g., Lindbladh et al., 2003; Olsson et al., 2010). Two Holocene charcoal records from bogs (Storasjö and Stavsåkra) in southern Sweden indicate that fire activity was mainly related to human land use during the past 2 ka (Fig. 1e; Greisman and Gaillard, 2009; Olsson et al., 2010; Olsson and Lemdahl, 2009; 2010). Species composition of the forest was also an important influence; e.g., the continuous presence of pine at Storasjö explains why there was more fire during the mid-Holocene than at Stavsåkra where pine was rare. Pine was the dominant tree at Storasjö from $A D 500$, while it was absent or rare at Stavsåkra until planted in the $20^{\text {th }}$ century (Fig. 1e). High macroscopic charcoal values ca. AD 1000-1200 may be related to the MCA. The data also indicate that the area was characterized by grazed Calluna (heather) heaths that were maintained by fire from $750 \mathrm{BC}$ until the $18^{\text {th }}$ century (Fig. 1e; Olsson et al., 2010; Olsson and Lemdahl, 2009, 2010). Dates from clearance cairns (Mounds of stones usually created by clearance of stones from fields for agricultural purposes) in the Stavsåkra region from 2000 BC to AD 1800 (Fig. 1e) document extensive forest clearing by burning (Skoglund, 2005). At Storasjö, macroscopic charcoal (Fig. 1e) correlates with dated fire scars on pine attributed to human-caused burning during the last 0.6 ka (Wäglind, 2004). The change from very frequent to no fires in the $18^{\text {th }}-19^{\text {th }}$ centuries in Sweden coincides with fire suppression (e.g., Niklasson et al., 2002; Lindbladh et al., 2003). Hence, human activities appear to have strongly shaped patterns of fire in parts of southern Sweden and northwestern Europe during the late Holocene.

\section{Conclusions}

The case studies here illustrate how the timing and consequences of anthropogenic interventions in natural fire regimes vary greatly across space and depend heavily on local ecological context; they also demonstrate why the cumulative global effects of anthropogenic impacts on fire regimes have been difficult to detect until the past two centuries (Fig. 2). Increasing efforts to synthesize existing paleoecological records (Power et al., 2009), and combine multiproxy evidence of paleoenvironmental changes with archeological data and modeling promise valuable advancements in our understanding of coupled human-natural systems in the past.

\section{Data}

All charcoal data discussed herein are available from the Global Charcoal Database (http:// www.ncdc.noaa.gov/paleo/impd/gcd.html)

\section{Acknowledgements}

We thank the Global Palaeofire Working Group (GPWG) for their contributions to the Global Charcoal Database - this research would not be possible without their efforts.

\section{References}

Marlon, J.R., Bartlein, P., Carcaillet, C., Gavin, D.G., Harrison, S.P., Higuera, P.E., Joos, F., Power, M.J. and Prentice, C.I., 2008: Climate and human influences on global biomass burning over the past two millennia, Nature Geoscience, 1: 697-701.

McWethy, D.B., Whitlock, C., Wilmshurst, J.M., McGlone, M.S., and Li, X. 2009: Rapid deforestation of South Island, New Zealand by early Polynesian fires, The Holocene, 19: 883-897.

Olsson, F., Gaillard, M.-J., Lemdahl, G. Greisman, A., Lanos, P., Marguerie, D., Marcoux, N, Skoglund, P. and Wäglind, J., 2010: A continuous record of fire covering the last 10,500 calendar years from southern Sweden - The role of climate and human activities, Palaeogeography, Palaeoclimatology, Palaeoecology, 291: 128-141.

Walsh, M.K., Whitlock, C. and Bartlein, P.J., in press: 1200 years of fire and vegetation history in the Willamette Valley, Oregon and Washington, reconstructed using high-resolution macroscopic charcoal and pollen analysis, Palaeogeography, Palaeodimatology, Palaeoecology.

Walsh, M.K., Whitlock, C. and Bartlein, P.J., 2008: A 14,300-year-long record of fire-vegetation-climate linkages at Battle Ground Lake, southwestern Washington, Quaternary Research, 70: 251-264.

For full references please consult:

http://www.pages-igbp.org/products/newsletters/ref2010_2.html 